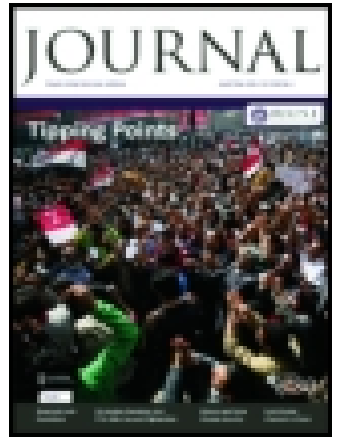

Royal United Services Institution. Journal

\title{
A German View Of British Tactics in The Boer War. How Far The Tactics and Peace-Training of The British Army Conduced To The Failures in S. Africa
}

Lieut.-Colonel E. Gunter

To cite this article: Lieut.-Colonel E. Gunter (1902) A German View Of British Tactics in The Boer War. How Far The Tactics and Peace-Training of The British Army Conduced To The Failures in S. Africa, Royal United Services Institution. Journal, 46:292, 801-806, DOI: 10.1080/03071840209419013

To link to this article: http://dx.doi.org/10.1080/03071840209419013

Published online: 11 Sep 2009.

Submit your article to this journal $\sqsubset$

Џll Article views: 9

View related articles $\square$ 


\title{
A GERMAN VIEIV OF BRITISH TACTICS IN THE BOER IVAR.
}

\author{
How far the Tactics and pence-Training of the \\ British ArMY CONDUCEd to the FaILUREs in S. AFrica. \\ Precis from the "Jahrlichcher für die Diutsche Armee und Ifarine." \\ B) Lieut.-Colonel E. GUNTER.
}

\begin{abstract}
X.B.-For brerity, 'I.D. stands for Infantry Drill, 1896. S. for section. s. for sub-section.

Since thi ; precis was male, the proviaional " hufantry Training" hat been isuct, showing how far our own Authorities' riews agree with German critici-m.-TR.
\end{abstract}

- IN the engagements of the first period of the Boer War the peacetraining of the British troops, based on their Drill Book, and taking no account of the experience already gained in that war, led to frequent repetitions of the same procedure which resulted in failure.

These tactics are to be attributed to the British having in framing their regulations paid too little attention to the experience of recent war's on a large scale, and to the teachings of sciencc, especially as regards ballistics, and to the fact that even where their regulations were unobjectionable, they were not skilfully carried out. In a word, their failures were attributable to their faulty peacc-training.

The existing English "Infantry Drill" of 1890 is in many respects similar to that of the German Army, and is a very clever pricis of tactical and technical military principles. It contains, however, some views and precepts which, owing partly to their direct influence and partly to their one-sided or narrow-minded comprehension by leaders, must certainly share the blame of the failures.

In almost all the actions of the first period of the war the British appronched the encmy in such deep formations that they suffered enormous loss. Now, I.D. S. 124 (5) advises no more extension than necessary. "Extension is only to be commenced when the hostile fire makes advance in closed bodies impracticable," and also that "it will often' be possible to advance to within 800 yards without extension,"

1 This is a mistranslation by the author-the scetion quotcl sars occasionally; moreover the remainder of tha sentenee, which the author doe; not gire, discounts this.-Tr. 
thus putting prominently forward the advantage of close formations. The author also, quoting from the rules for manœuvres, says, "troops when under well-conducted, effective fire are not to approach nearer the enemy's position than $\mathbf{8 0 0}$ yards in close:formation." (This paragraph was, however, altered in the " Rules" published in July, 1899, to 1,500 yards, and the distance at which bodies can only move directly to the front or rear, which the author condemns as too close (700 yards), was altered to i,000 yards.)

He says the above shows the tendency towards close formations, and that, moreover, the rules for savage warfare in the Drill Book order close formations to be adhered to whenever possible. "The regulations were more framed with regard to the increasing wars in India and Africa, and so close formations were much more practised than skirmishing, which entails much greater trouble and higher intelligence."

Perhaps the British thought at first the Boers were half savages. They suffered the same experience as the Germans against the troops of the French Empire in 1870, only the Boers were far superior to the French in weapons and their use.

This massing of the troops is also influenced by the fact of the battalion being much more the tactical unit than in the German Army. ${ }^{1}$ And the Line formations advancing and retiring in line, etc., are much more constantly practised in battalion drill. The directions for the calculation of frontage on the principle that it shall not exceed in attack that of the line in close order, so that a brigade extended only covers 585 yards, and in defence five men per pace are required, have the same tendency.

A second fault is the insufficient preparation of the attack by fire. The directions for carrying out the assault and for counter-attack show that the authorities have not yet been able to shake off the tendency to shock tactics.

The regulations prescribe 3,000 yards as the limit of artillery range. The British artillery were. however, soon forced to open fire at much greater range, but, owing to want of practice, with very little effect.

The English are still adherents of volley firing, which we Germans have given up years ago. They only permit individual and independent fire when within 500 yards. The rule is to fire section volleys. The want of careful individual training and the anxiety to pull his trigger the moment the word is given result in each man's firing without taking exact aim. Only one-fourth (one section) or at most half of each company is to be extended. 
The English open fire too late. The regulations say, as a rule, fire will not be opened in attack till the troops reach medium range, and that the troops should try and get as near the enemy as possible before opening fire, this precept being repeated in the instructions for company drill. The advance by rushes is described, and the author says it is expected that by the time a distance of 500 yards from the position is reached, so great an effect will have been produced by the preparatory and decisive fire, that real and false attacks will be able to be made upon the position as from a siege-parallel. But still the enemy's defeat is not completed till 300 yards from the position, for from that distance, bayonets having been fixed, magazine fire (five rounds) is to be opened.

These directions must inevitably train the troops to too great delay in opening fire, and to devote too short a time and too few rifles to the preparatory fire.

The effect of the distribution of the attacking force by depth also makes itself felt. The English regulations leave the whole fire-fight, that is the main task, the establishment of superiority of firc, to the first line, and does not allow the second line to take any part in it $^{1}$ until the moment for the assault comes, which if superiority of fire has been well established, is comparatively easy work. The second line is required to be closed upon the first the moment the latter has established thorough superiority of fire, and to carry the first line by its impulse forward with it to storm the breach.

Now, this is a work of art. How is the second line to judge exactly when it is to press forward? If it is too late the first line may be destroyed and the fight have to be begun anew. If too soon, then it may force the fighting and oblige the first line to intermingle with it. The defender, not yet sufficiently shaken, will repulse the thickened line with bloody loss.

The attack being thus conclucted on the paradc grounds, it is but natural that the energies of the first line should diminish with each succeeding drill, and the heavy assault with beat of drum, blast of bugle, and loud hurrah, become more and more the main business, especially with the hurry-scurry that always characterises sham-fights. Hence, the main thing in attack becomes the rush to the assault, not the preparation by fire.

The engagements in South Africa took this course. The British troops run in close formations into the effective fire range of the Boers, suffer great loss, and then begin their fire-fight. The second line advances after very inadequate preparation, undertakes the assault with

This is not quite correct, as I.D.S. 111 (2) permits the second line to reinfurce the first at any time requirel. $-\mathrm{T}$. 
portions of the first line, and is repulsed with heavy loss by the still unshaken defenders.

Buller's, Methuen's, and Gatacre's actions took this form. General' Symons tried three times in vain to force the enemy's position at Glencoe by frontal attack. On 23rd February, Gencral Buller let the 2nd and 5th Brigades in succession make frontal attacks against Picter's Hill and Grobler's Kloof, though this had been unsuccessfully attempted by the 11th Brigade the day before.

The writer then criticises I.D. S. 124 (4), by which the third line is directed to take up a defensive position to rally on in case of reverse, remarking that the German regulations prescribe that, when.required, the last reserve is to be engaged. He also says that the same measure of over-caution characterises the instructions for the defence, the commander being required to keep a reserve in hand to be employed for counterattack or to cover the retreat, whereas the Germans say it should be used to carry out the fight itself. The result of this is, he remarks, that the troops are only partially employed and failures in detail occur, which, bringing the whole into action, would obviate, e.g., at Spion Kop, at the decisive moment, only 4,000 men of Woodgate's Brigade were made use of, while 3.600 remained inactive. At Magersfontein the Highland Brigade, supported by a portion only of the Guards, had to bear the whole burden of the fight, while the other portion and the 9th Brigade took no part in the action.

The writer criticises the British quick advance and the method of attack by short rushes of $\mathbf{4 0}$ to $\mathbf{5 0}$ yards, whereas the Germans prefer those from 80 to 100 long. The advantages of short rushes are less fatigue, shorter exposure to the defender'saim, and less interruption of fire. On the other hand, the more often repeated exposure of the mon at the moment of rising to rush forward causes greater loss in the end. The moral effect of the larger number rushing forward less frequently is greater. ${ }^{1}$

Against good snap-shots like the Boers the device of quick, short rushes were ineffectual.

The writer criticises also the instruction "firing as they go" of I.D. S. $115(2)$, saying that firing while advancing to the assault has been done away with in the German Infantry Drill; that such firing is quite useless against an enemy who offers no more at most than a head and shoulders to aim at.

The British troops were far inferior to the Boer in their knowledge of the use of ground. Mostly recruited from the towns, this was

\footnotetext{
I According to a German eye-witness, the British rishes were tor long, as giving time for defcuder's nim.-TR.
} 
unknown to them, and in their peace training they were not instructed in this. The Drill Book makes occasional mention of it, but does not say how it is to be done. It, therefore, happened in the first part of the campaign that officers and men alike despised the use of cover. To the preparation for battle as regards training the men to judge ground and distances, the exigencies of the fight, fire discipline, and skilful use of weapons, which demand a high order of knowledge and capacity as well as considerable mental activity on the part of instructing officers, very little time or zeal had been devoted, and, even where this was occasionally done, more attention was paid to practising effective battle-pictures, without taking into account their practical accordance with real war.

In no modern Army does "drill" flourish as in the British. We see everywhere the most exaggerated stress laid on uniformity and simultaneous action. Their ideal is to get movements done so that they look well and the "now all together" principle rules supreme. We see that even in their musketry instruction and shooting. Stiffness and uniformity characterised the performance of the individual skirmisher as well as the collective action of small bodies or of detachments. The Infantry Drill of 1896, brought out under the auspices of the highlygifted and honoured Lord Wolseley, certainly indicated progress in recognising the higher value of the spirit of things as compared with mere form. But the training of the troops was still entrusted to the men of tradition. These could not bring themselves to believe that the practices they had (with more or less success) taught before the introduction of the new drill had suddenly become useless or at least of minor importance. This and the trouble of striking out new paths for themselves were obstacles to the penetration of the proper spirit of the new regulations. Therefore, though they adopted the minor changes in form which these introduced, they retained, essentially, their old methods of training. Even Lord Wolseley's inspections, to the disappointment of some progressive officers, were modelled on the old type.

The antiquated system of training of the British Army is partly owing to the troops not being allowed to go off the roads while exercising, unless the landowner especially gives permission for this in each case. Their training was, therefore, that of the parade ground, which made instruction in the use of ground impracticable. When, therefore, they took part in mancuvres on a large scale, as near Aldershot and on Salisbury Plain, though there was ample room and variety of ground, they did not take advantage of this, because they had never had individual practice in this, nor had they even when working in small bodies been accustomed to it.

1 The writer has apparently orerlooked I.D. S. 47 (5)., -Tr. 
The above-named mancuvre grounds themselves, though certainly large enough and suitable for the technical training of bodies of troops of all arms, are not sufficient for the technical training of officers and for practising the combats of opposing forces of all arms. The nature of the ground and its various obstacles, irregularitics, its cover, distances, etc., become in a short time so thoroughly known to all the officers engaged that they only learn the tactics suitable to that particular locality. For real tactical training and for the essential practice in reconnaissance it is necessary to work over ground that is contirfually changing, so that, from its rature, fresh problems may always present themselves for solution. 